\title{
Experimental Neonatal Respiratory Failure Induced by a Monoclonal Antibody to the Hydrophobic Surfactant-Associated Protein SP-B
}

\author{
BENGT ROBERTSON, TSUTOMU KOBAYASHI, MASAYA GANZUKA, GERTIE GROSSMANN, \\ WEN-ZHI LI, AND YASUHIRO SUZUKI

\begin{abstract}
Department of Anesthesiology, Kanazawa University, Kanazawa, Japan [M.G., T.K., W-Z.L.]; Department of Molecular Pathology, Kyoto University, Kyoto, Japan [Y.S.]; and Research Unit for Experimental Perinatal
\end{abstract} \\ Pathology, St. Göran's Hospital, Stockholm, Sweden [G.G., B.R.]
}

\begin{abstract}
The present experiments were designed to test whether selective blocking of the surfactant-associated hydrophobic polypeptide SP-B $(8.7 \mathrm{kD})$ would interfere with lung function during neonatal adaptation. A MAb to porcine SP-B was produced by hybridoma cell line (8B5E); this antibody cross-reacts with rabbit SP-B. Six mg of MAb to SP-B, dissolved in $0.2 \mathrm{~mL}$ of saline, was instilled into the airways of near-term newborn rabbits (gestational age $29 \mathrm{~d}$ ), before the onset of ventilation. Control animals received the same amount of nonspecific rabbit IgG in saline, or were untreated. The animals were ventilated for $120 \mathrm{~min}$ with a standardized tidal volume $(10 \mathrm{~mL} / \mathrm{kg})$. The specific antibody caused a prominent, immediate decrease in lung-thorax compliance, associated with acute inflammatory and exudative lung lesions including hyaline membranes. IgG alone had no such effects. Our data suggest that the MAb to SP-B inhibits surfactant function in the neonatal period by blocking one of the mechanisms responsible for fast adsorption of the surfactant phospholipids to the alveolar air-liquid interface. In addition, an acute inflammatory reaction is probably triggered in the lung parenchyma by the immune reaction. (Pediatr Res 30: 239-243, 1991)
\end{abstract}

\section{Abbreviations}

SP-B, surfactant protein B $(8.7 \mathrm{kD})$

$V_{v}$, volume density

The surfactant-associated proteins SP-B $(8.7 \mathrm{kD})$ and SP-C $(4.2 \mathrm{kD})$ are hydrophobic polypeptides that accelerate the adsorption of the surfactant lipids to an air-liquid interface (1-5). These proteins seem to be essential components of "natural" surfactant preparations for replacement therapy (1). Because the rapid adsorption of lung surfactant is a prerequisite of normal respiratory adaptation in the neonatal period $(6,7)$, we wondered whether selective blocking of one of these proteins in the mature neonatal lung would lead to pulmonary maladaptation or to structural and functional abnormalities similar to those charac-

Received July 20, 1990; accepted March 25, 1991.

Correspondence: Bengt Robertson, M.D., Department of Pathology, St. Göran's Hospital, S-112 81, Stockholm, Sweden.

Supported by the Swedish Medical Research Council (Project No. 3351), Oscar II:s Jubileumsfond, Axel Tielman's Minnesfond, the General Maternity Hospital Foundation, the Royal Swedish Academy of Sciences, and the Japan Society for the Promotion of Science (travel grants to G.G. and B.R.), Grant-in-Aid of Japan Medical Association, and Grant-in-Aid for Scientific Research from the Ministry of Education, Science and Culture of Japan (Project No. 02454352). terizing the respiratory distress syndrome. In the present experiments, we tested this hypothesis by exposing the lungs of nearterm newborn rabbits to a MAb against the larger of the hydrophobic surfactant-associated proteins, SP-B.

\section{MATERIALS AND METHODS}

Isolation and separation of surfactant-associated hydrophobic proteins. Surface active material was prepared from pig and rabbit lung homogenates as described by Frosolono et al. (8). The surfactant-associated hydrophobic protein fraction was isolated from the surfactant lipids by chromatography on Sephadex LH60 (3). The hydrophobic proteins were separated by SDSPAGË (12.5\%) according to Weber and Osborn (9). For immunoblotting (see below), the protein fractions were adsorbed onto Dulapore sheets (Nihon Millipore Kogyo K.K., Yonezawa, Japan) (10).

Isolation and characterization of MAb. A MAb to porcine SP$\mathrm{B}$ was produced by methods previously described by Suzuki et al. (11). In brief, spleen cells from adult mice, immunized against porcine SP-B, were fused with myeloma cells. The specificity of the antibody produced by the hybridoma cell line (8B5E) was confirmed by immunoblotting, using biotinylated antibody (11). There was a prominent reaction to porcine SP-B but no reaction to porcine SP-C (Fig. 1 $A$ ). The antibody cross-reacted strongly with rabbit SP-B, without additional binding to rabbit SP-C (Fig. $1 B)$. The MAb produced by the hybridoma cell line (8B5E) inhibited the physiologic activity of porcine surfactant in a Wilhelmy balance system, as indicated by retarded film adsorption and elevated minimum surface tension during cyclic film compression (12).

Animal model. Experiments were performed on a total of 26 rabbit fetuses from four litters, delivered by hysterotomy at a gestational age of $29 \mathrm{~d}$ (term, $31 \mathrm{~d}$ ). At this stage of fetal development, adequate amounts of surfactant have usually accumulated in the alveolar spaces and the lungs are, therefore, easily expanded with gas at birth (13). The newborn rabbits were weighed, anesthetized with intraperitoneal pentobarbital sodium $(0.5 \mathrm{mg})$, relaxed with intraperitoneal pancuronium bromide $(0.02 \mathrm{mg})$, and tracheotomized. In each litter the animals were randomized to receiving, via the tracheal cannula, either $6 \mathrm{mg}$ of MAb to SP-B in $0.2 \mathrm{ml}$ normal saline $(n=8)$ or $6 \mathrm{mg}$ of nonspecific rabbit IgG (Sigma Chemical Co., St. Louis, MO) in the same volume of saline $(n=9)$, or to serve as nontreated controls $(n=9)$.

The neonates were then transferred to a system of multiple body plethysmographs, heated to $37^{\circ} \mathrm{C}$, and connected in parallel to a common ventilator system delivering $100 \%$ oxygen at a frequency of $40 / \mathrm{min}$ and an inspiration:expiration ratio of $1: 1$. Insufflation pressure was individually adjusted (14) to provide a 


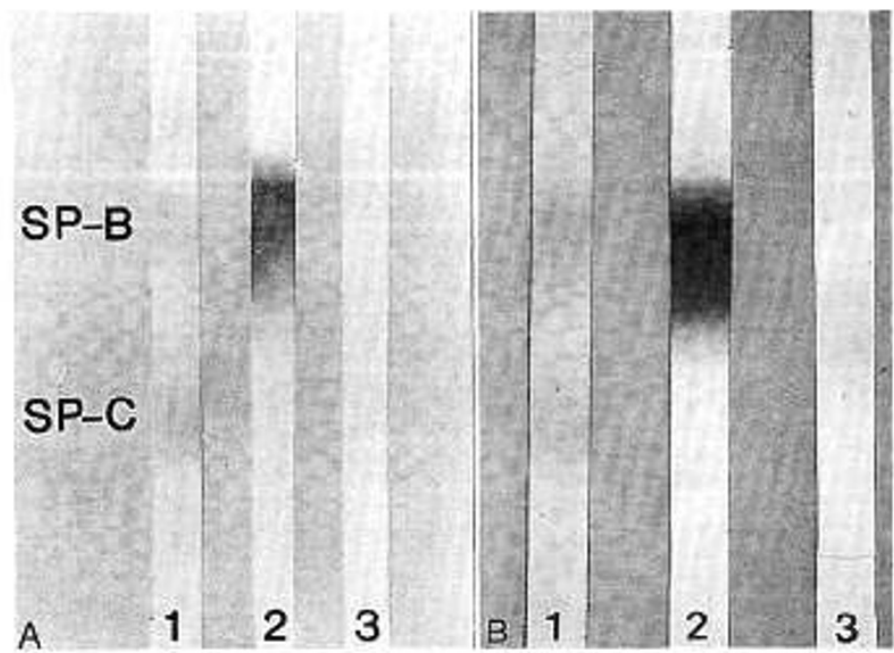

Fig. 1. Immunoblots documenting selective binding of the MAb to surfactant-associated hydrophobic protein SP-B, isolated from pig lungs $(A)$ and to SP-B isolated from rabbit lungs $(B)$ without additional binding to SP-C. The hydrophobic protein fraction was isolated from the surfactant lipids by chromatography on Sephadex LH60 (3), separated by SDSPAGE (12.5\%) (9), and blotted to a Dulapore sheet. Lane 1 , amido black stain; lane 2, incubation with biotinylated antibody; lane 3, control without antibody.

tidal volume of approximately $10 \mathrm{~mL} / \mathrm{kg}$ body weight. Tidal volumes were measured by means of a pneumotachygraph connected to the plethysmograph box (15). Animals were ventilated for $120 \mathrm{~min}$, and simultaneous recordings of insufflation pressure and tidal volumes were obtained every $15 \mathrm{~min}$. Lung-thorax compliance was calculated by dividing tidal volume with peak insufflation pressure. ECG was obtained from subcutaneous needle electrodes after $60 \mathrm{~min}$ and $120 \mathrm{~min}$

After the period of artificial ventilation, the animals were killed by intracerebral injection of lidocaine (this causes immediate cardiac arrest). Each abdomen was opened and the diaphragm inspected for evidence of pneumothorax. Thereafter each chest was opened in the anterior midline and blood was sampled from the usually bulging right cardiac ventricle for determination of $\mathrm{PCO}_{2}$ and $\mathrm{pH}(16)$.

The dead animals were connected in parallel to an equipment for static lung pressure-volume recordings (17). Airway pressure was raised stepwise from 0 to $30 \mathrm{~cm} \mathrm{H}_{2} \mathrm{O}$ and then lowered stepwise to $0 \mathrm{~cm} \mathrm{H}_{2} \mathrm{O}$, allowing 1 min of stress relaxation at each $5-\mathrm{cm}$ level. Volume measurements were corrected for gas compression.

A catheter was tied into the pulmonary trunk, and the lungs were fixed with $10 \%$ neutral formalin, infused for $30 \mathrm{~min}$ into the pulmonary arterial system at a pressure of $65 \mathrm{~cm} \mathrm{H}_{2} \mathrm{O}$. Before the fixative was instilled, the lungs were first inflated for $1 \mathrm{~min}$ with a transpulmonary pressure of $30 \mathrm{~cm} \mathrm{H}_{2} \mathrm{O}$ and then deflated to a pressure level of $10 \mathrm{~cm} \mathrm{H}_{2} \mathrm{O}$; this pressure was maintained during the perfusion procedure.

The whole lungs were excised, stored in $4 \%$ neutral formalin, and embedded in paraffin. Large transverse sections from the lower lobes, stained with hematoxylin and eosin, were examined by conventional light microscopy with particular reference to the alveolar expansion pattern, hemorrhage, desquamation of airway epithelium, and inflammatory and exudative lesions including hyaline membranes. In addition, $V_{V}$ of alveolar spaces was determined by point counting, using total parenchyma as reference volume.

Statistical analysis. All data are presented as mean (SD). Differences between the groups were evaluated with the Wilcoxon two-sample test (two-tailed).

\section{RESULTS}

General observations. There were no differences in body weight between the three groups. In final ECG recordings, two of the animals receiving MAb had atrioventricular block with a heart rate below 150 beats/min, and one animal receiving nonspecific IgG had no regular cardiac activity, only P-waves. This latter animal (showing atrioventricular block already at the 60-min recording) was excluded from further analysis. All other animals had normal ECG throughout the period of observation. Animals receiving the $\mathrm{MAb}$ had increased $\mathrm{PCO}_{2}$ and lowered $\mathrm{pH}$ in heart blood sampled at the end of the experiment. Blood gases in surviving animals receiving nonspecific IgG did not differ significantly from those of nontreated controls (Table 1).

Lung-thorax compliance. A significantly higher pressure was required to maintain the standardized tidal volume in animals receiving the antibody (Fig. 2), indicating a reduction of lungthorax compliance. The difference versus the nontreated control group, established already at the first regular recording $15 \mathrm{~min}$ after the onset of ventilation, persisted throughout the period of observation. Instillation of nonspecific rabbit IgG had no such effect; the compliance values in this group were not significantly different from those of nontreated control animals at corresponding time intervals (Table 2).

Static pressure-volume recordings. In animals treated with the $\mathrm{MAb}$, the maximal volume was much lower than in the control group, and the volumes remained low throughout the deflation limb of the pressure-volume diagram. Again, animals receiving nonspecific IgG did not differ from nontreated controls (Fig. 3).

Histologic and morphometric observations. All animals receiving the MAb showed the same pattern of abnormalities in the histologic sections, characterized by poor or only patchy alveolar expansion (Fig. 4A), widespread accumulation of amorphous material in the terminal airspaces (interpreted as proteinaceous intraalveolar edema and/or unresorbed fetal lung liquid), alveolar hyaline membranes, focal intraalveolar hemorrhage, and a moderate-to-prominent inflammatory reaction with presence of neutrophilic and eosinophilic granulocytes both in the perivascular interstitial tissue and in the alveolar spaces (Figs. $5 \mathrm{~A}$ and $B)$. There was also extensive desquamation of bronchiolar epithelium, and many peripheral airways were plugged with cell debris including pyknotic nuclei from necrotic epithelium. In some areas, desquamating necrotic cells were also identified in alveoli.

No such lesions were observed in animals receiving nonspecific IgG or in nontreated controls. A few animals in each of these groups showed focal atelectasis and minor areas of intraalveolar edema (or unresorbed fetal lung liquid), and a discrete focal accumulation of granulocytes was observed in one of the nontreated controis. Otherwise these lungs were essentially normal, with well-expanded terminal airspaces (Figs. $4 B$ and $C$ ).

The differences among the groups were clearly documented by the morphometric findings. Animals treated with the MAb had significantly reduced alveolar $V_{v}$, whereas the values for animals receiving nonspecific IgG did not differ from nontreated controls. The comparatively high field-to-field variability of alveolar expansion in lung sections from animals treated with $\mathrm{MAb}$ was reflected by an elevated value for the coefficient of variability of alveolar $\mathrm{V}_{\mathrm{v}}$ (Table 3 ).

\section{DISCUSSION}

The present findings show that severe structural and functional abnormalities can be induced in the neonatal lung by tracheal instillation of a MAb to SP-B. Lung lesions were similar to those induced by the same antibody in adult mice, after inoculation of the hybridoma cells in the abdominal cavity $(18,19)$. Respiratory failure was not the result of nonspecific inactivation of surfactant, caused by the presence of rather large amounts of $\mathrm{Ig}$ in the airspaces; instillation of the same dose of IgG had no influence 
Table 1. General observations including heart rate after 120 min and final blood gases in animals surviving the period of ventilation*

\begin{tabular}{|c|c|c|c|c|c|}
\hline \multirow[b]{2}{*}{ Treatment at birth } & \multirow{2}{*}{$\begin{array}{c}\text { No. of } \\
\text { survivors }\end{array}$} & \multirow{2}{*}{$\begin{array}{l}\text { Body } \\
\text { weight } \\
\text { (g) }\end{array}$} & \multirow{2}{*}{$\begin{array}{l}\text { Heart rate } \\
\text { in survivors } \\
\text { (beats/min) }\end{array}$} & \multicolumn{2}{|c|}{ Blood gases } \\
\hline & & & & $\mathrm{PCO}_{2}(\mathrm{kPa})$ & $\mathrm{pH}$ \\
\hline $\mathrm{MAb}$ & $8 / 8$ & $37(8)$ & $208(67)$ & $9.08(2.47) \dagger$ & $7.02(0.29) \ddagger$ \\
\hline Nonspecific IgG & $8 / 9$ & $45(8)$ & $241(14)$ & $7.29(1.88)$ & $7.30(0.14)$ \\
\hline Nontreated controls & $9 / 9$ & $42(7)$ & $249(19)$ & $6.07(1.44)$ & $7.36(0.05)$ \\
\hline
\end{tabular}

* Values are given as mean (SD).

$\dagger p$ vs nontreated controls $<0.02$.

$\ddagger p$ vs nontreated controls $<0.002$.

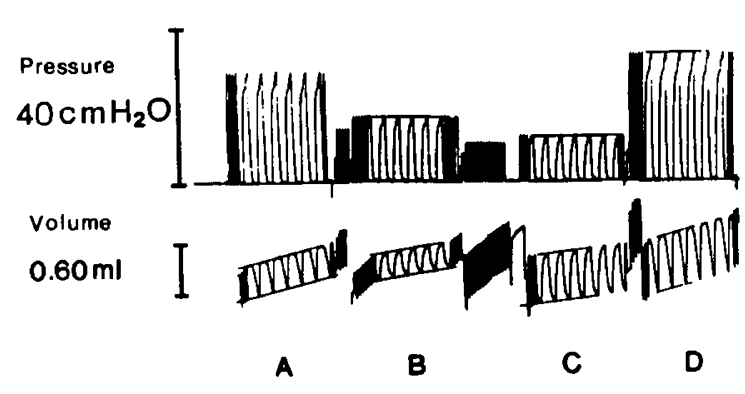

Fig. 2. Original recordings of insufflation pressures (upper panel) and tidal volumes (lower panel) in four near-term newborn rabbits, obtained after $120 \mathrm{~min}$ of ventilation with a standardized tidal volume of approximately $10 \mathrm{~mL} / \mathrm{kg}$. The pressure required to maintain this tidal volume is about twice as high in the animals receiving MAb to SP-B $(A, D$; body weights 31 and $51 \mathrm{~g}$, respectively) as in those receiving nonspecific $\mathrm{IgG}$ $(C ; 59 \mathrm{~g})$ or no material via the tracheal tube $(B ; 29 \mathrm{~g})$.

Table 2. Lung-thorax compliance at various time intervals after onset of ventilation in animals receiving $M A b$ to $S P-B$ or nonspecific $\operatorname{Ig} G$, and in nontreated controls*

\begin{tabular}{lccccc}
\hline & \multicolumn{5}{c}{ Compliance $\left(\mathrm{mL} / \mathrm{cm} \mathrm{H}_{2} \mathrm{O} \cdot \mathrm{kg}\right) /$ time $(\mathrm{min})$} \\
\cline { 2 - 6 } Treatment at birth & 15 & 30 & 60 & 90 & 120 \\
\hline $\mathrm{MAb}$ & $0.42 \dagger$ & $0.38 \dagger$ & $0.38 \dagger$ & $0.35 \dagger$ & $0.35 \dagger$ \\
& $(0.07)$ & $(0.06)$ & $(0.04)$ & $(0.06)$ & $(0.04)$ \\
Nonspecific IgG & 0.87 & 0.89 & 0.90 & 1.00 & 0.79 \\
& $(0.23)$ & $(0.20)$ & $(0.20)$ & $(0.19)$ & $(0.12)$ \\
Nontreated controls & 1.10 & 1.09 & 1.07 & 0.93 & 0.88 \\
& $(0.45)$ & $(0.48)$ & $(0.36)$ & $(0.27)$ & $(0.19)$ \\
\hline
\end{tabular}

* Values are given as mean (SD).

$\dagger p$ vs nonspecific IgG and nontreated controls, each $<0.002$.

on lung compliance and did not trigger the exudative lesions found in the lungs of animals receiving the MAb.

Specific binding of the antibody to SP-B was confirmed in the present study by immunoblotting, using isolated pig and rabbit hydrophobic lung protein fractions. Strong cross-reaction to SP$B$ isolated from rabbit lung indicated homology within the immunogenic epitopes of the proteins involved. We do not know whether the noxious effects observed in the present experimental model would have been even more prominent if we had used a MAb to homologous (rabbit) SP-B. The amount of antibody instilled into the airways of experimental animals was based on previous data from in vitro studies indicating that the surface adsorption of porcine surfactant [Curosurf ( $C u$ rstedt and Robertson surfactant), diluted to a concentration of $10 \mathrm{mg} / \mathrm{mL}$ ] is significantly retarded at an antibody concentration of $0.5 \mathrm{mg} /$ $\mathrm{mL}$, and that the surface-tension lowering properties of the same surfactant preparation during surface compression are nearly completely inhibited at an antibody concentration of $2 \mathrm{mg} / \mathrm{mL}$ (Y. Suzuki et al., unpublished observations). These concentrations correspond to approximate antibody-to-SP-B molar ratios of $1: 2$ and 2:1, respectively. Assuming that the pool size of surfactant in the airspaces of a near-term newborn rabbit amounts to about $20 \mathrm{mg}$ phospholipids and $4 \mathrm{mg}$ low mol wt

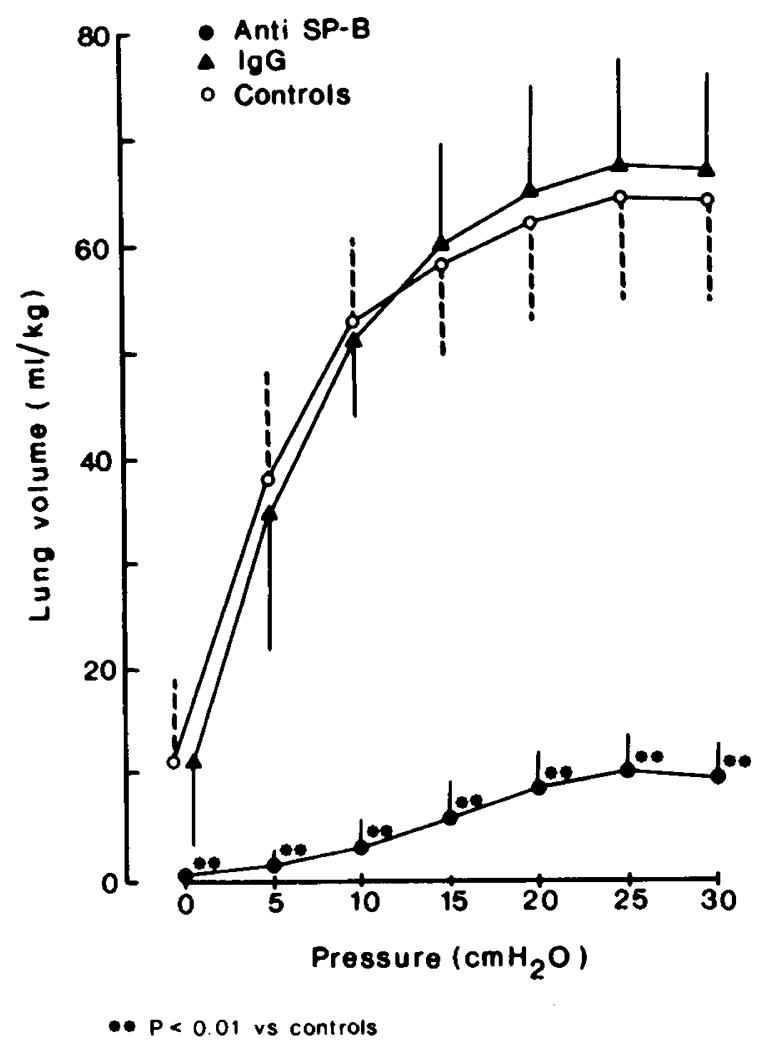

Fig. 3. Deflation limbs of static pressure-volume recordings showing significantly lower lung volumes in animals receiving MAb to SP-B; animals receiving nonspecific $\mathrm{IgG}$ do not differ from controls. ${ }^{*} p$ vs controls $<0.01$.

apoprotein per $\mathrm{kg}$ body weight (20) (which in a $50-\mathrm{g}$ rabbit neonate would correspond to $1 \mathrm{mg}$ phospholipids and about 0.1 $\mathrm{mg} \mathrm{SP-B}$ ), we estimated that at least $4 \mathrm{mg}$ of the antibody would be required for complete in situ inhibition of surfactant. The dose of antibody $(6 \mathrm{mg})$ administered in the experimental animals may have been in excess relative to the minimum amount required to trigger a full-blown pathophysiologic reaction, but that particular aspect was not further investigated in the present study.

The prominent functional and histopathologic changes observed in our experimental model can be explained by at least two mechanisms. One obvious possibility is that direct inactivation SP-B in the fetal lung liquid leads to a disturbance of surfactant function, with delayed adsorption of surfactant lipids to the air-liquid interfaces of the expanding lung and failure to stabilize alveoli at end-expiration. This interpretation is supported by in vitro studies (12) showing significantly prolonged adsorption time and elevated minimum surface tension during surface compression in samples of porcine surfactant mixed with the MAb. The very rapid establishment of the functional disturbance (with a decrease in compliance to about $40 \%$ of control values within $15 \mathrm{~min}$ ) is in keeping with this concept. The 

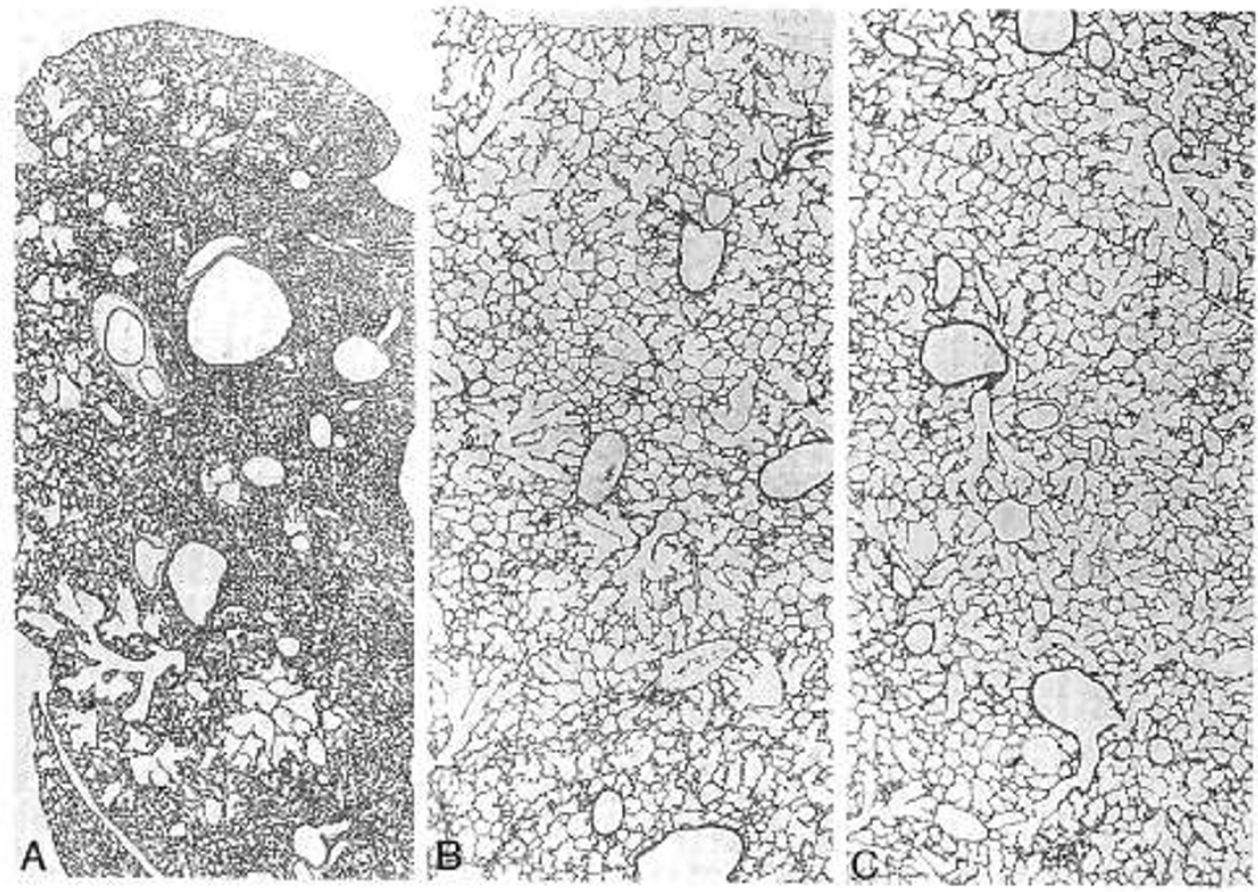

Fig. 4. Low-power histologic fields showing widespread alveolar collapse in animal receiving MAb to SP-B ( $A$ ), and well-aerated alveoli in animal receiving nonspecific $\operatorname{IgG}(B)$ as well as in a nontreated control animal $(C)$. Hematoxylin and eosin, $\times 15$.

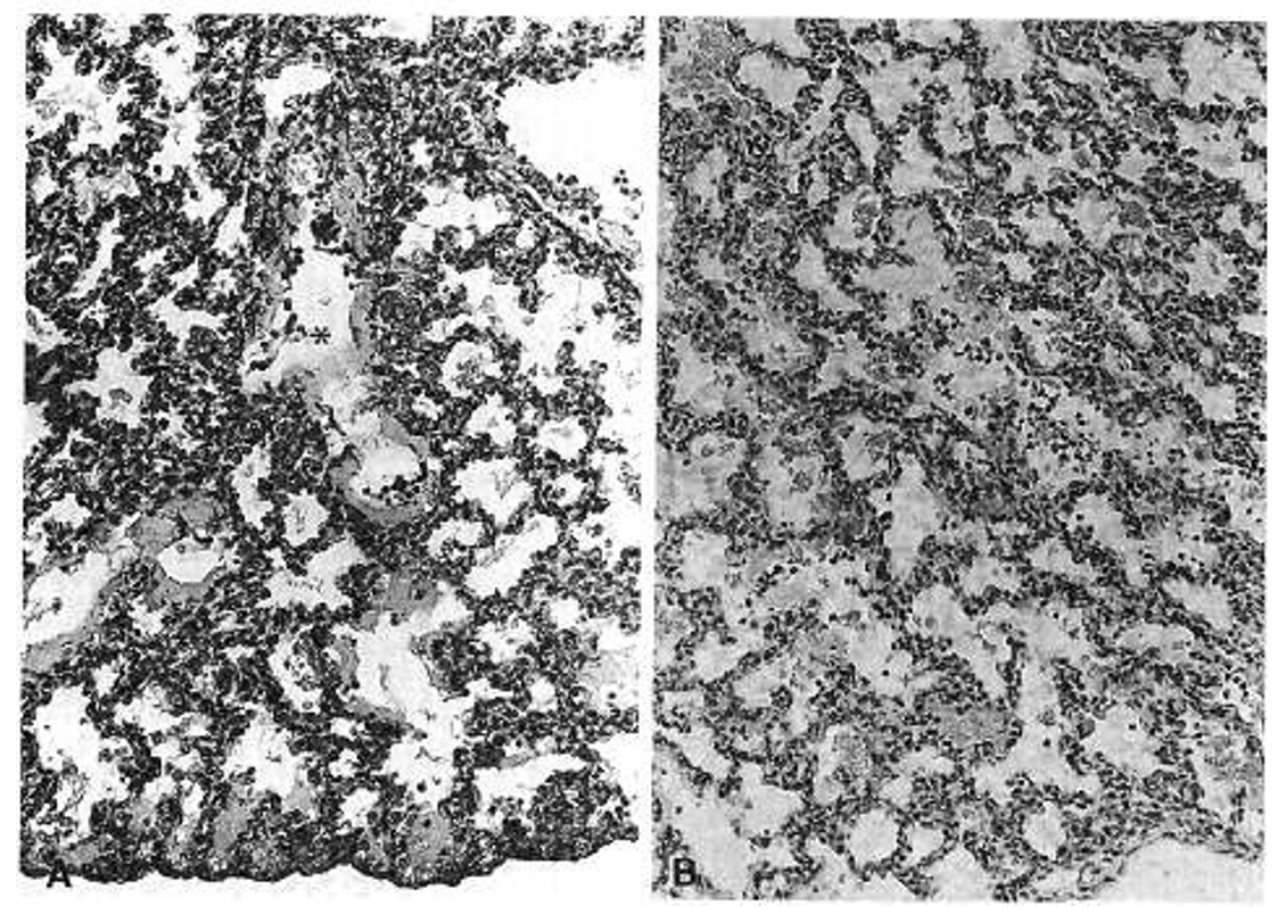

Fig. 5. Details showing lung parenchymal lesions in animals receiving MAb to SP-B. A: Many alveoli are nearly collapsed and there is epithelial necrosis with hyaline membranes in both bronchioles $\left({ }^{*}\right)$ and alveoli. $B$ : Hemorrhagic intraalveolar edema associated with moderate accumulation of granulocytes in the airspaces. Hematoxylin and eosin, $\times 120$.

Table 3. Morphometric findings*

\begin{tabular}{lll}
\hline Treatment at birth & $\begin{array}{c}\text { Alveolar } \\
\mathrm{V}_{\mathrm{v}}\end{array}$ & $\begin{array}{c}\text { Coefficient of } \\
\text { variability of } \\
\text { alveolar } \mathrm{V}_{\mathrm{v}}\end{array}$ \\
\hline MAb & $0.40(0.10) \dagger$ & $0.23(0.04) \dagger$ \\
Nonspecific IgG & $0.69(0.07)$ & $0.14(0.05)$ \\
Nontreated controls & $0.69(0.08)$ & $0.14(0.05)$ \\
\hline
\end{tabular}

* Values are given as mean (SD).

$\dagger p$ vs nontreated controls $<0.002$. "surfactant-inactivation scenario" would include mechanical disruption of bronchiolar and alveolar epithelium, from shear forces secondary to irregular expansion of the parenchyma during the ventilatory movements (21). Such epithelial lesions are regularly observed in surfactant-deficient preterm rabbits, ventilated under similar conditions (22). Another possibility is that the structural and functional lung lesions are triggered by SP-B-anti-SP-B immune complexes via an immunologic cascade with activation of complement, resulting in epithelial necrosis, recruitment of granulocytes to the site of damage, release of proteolytic enzymes, additional epithelial damage with leakage of serum proteins into 
the airspaces, inactivation of surfactant and so forth (i.e., the sequence of events incriminated in the pathogenesis of the adult respiratory distress syndrome) (23). Epithelial necrosis in airways and alveoli belongs to the spectrum of structural abnormalities characterizing neonatal respiratory distress syndrome (21), but these lung lesions are usually not associated with the type of acute inflammatory reaction noted in the present study in animals receiving the MAb.

We believe the complex histopathologic changes observed after exposure to the MAb are best explained by a combination of surfactant inactivation and tissue injury mediated by immune complexes. We speculate that a similar (albeit autoimmune) reaction could aggravate any type of lung disease associated with increased alveolar permeability and possible leakage of surfactant-associated proteins into the bloodstream (24).

\section{REFERENCES}

1. Whitsett JA, Ohning BL, Ross G, Meuth J, Weaver T, Holm BA, Shapiro DL Notter RH 1986 Hydrophobic surfactant-associated protein in whole lung surfactant and its importance for biophysical activity in lung surfactant extracts used for replacement therapy. Pediatr Res 20:460-467

2. Yu SH, Possmayer F 1986 Reconstitution of surfactant activity by using the $6 \mathrm{kDa}$ apoprotein associated with pulmonary surfactant. Biochem J 236:8589

3. Curstedt T, Jörnvall H, Robertson B, Bergman T, Berggren P 1987 Two hydrophobic low-molecular-mass protein fractions of pulmonary surfactant. Characterization and biophysical activity. Eur J Biochem 168:255-262

4. Yu SH, Wallace D, Bhavnani B, Enhorning G, Hardling PGR, Possmayer F 1988 Effect of reconstituted pulmonary surfactant containing the 6000 dalton hydrophobic protein on lung compliance of prematurely delivered rabbit fetuses. Pediatr Res 23:23-30

5. Revak SD, Merritt TA, Degryse E, Stefani L, Courtney M, Hallman M, Cochrane GC 1988 Use of surfactant low molecular weight apoproteins in the reconstitution of surfactant biologic activity. J Clin Invest 81:826-833

6. Clements JA 1977 Functions of the alveolar lining. Am Rev Respir Dis 115:6771

7. Bangham AD, Morley CJ, Phillips MC 1979 The physical properties of an effective lung surfactant. Biochim Biophys Acta 573:552-556

8. Frosolono MF, Charms BL, Pawlowski R, Slivka S 1970 Isolation, characterization and surface chemistry of a surface active fraction from dog lung. $J$ Lipid Res 11:439-457
9. Weber K, Osborn M 1969 The reliability of molecular weight determinations by dodecyl sulphate-polyacrylamide gel electrophoresis. J Biol Chem 244:4406-4412

10. Towbin H, Staehelin T, Gordon J 1979 Electrophoretic transfer of protein from polyacrylamide gels to nitrocellulose sheets: procedure and some applications. Proc Natl Acad Sci USA 76:4340-4354

11. Suzuki Y, Kogishi K, Fujita Y, Kina T, Nishikawa S 1986 A monoclonal antibody to the 15,000 dalton protein associated with porcine pulmonary surfactant. Exp Lung Res 11:61-73

12. Suzuki $Y$, Kogishi K, Fujita $Y 1986$ Ultrastructural localization and its possible role on the surface activity of the 15,000 dalton protein associated with pig pulmonary surfactant. J Jpn Med Soc Biol Interface 17:76-82

13. Nilsson R 1979 Lung compliance and lung morphology following artificia ventilation in the premature and full-term rabbit neonate. Scand J Respir Dis 60:206-214

14. Sun B, Kobayashi T, Curstedt T, Grossmann G, Robertson B 1991 Application of a new ventilator-multi-plethysmograph system for testing efficacy of surfactant replacement in newborn rabbits. Eur Respir J 4:364-370

15. Lachmann B, Grossmann G, Freyse J, Robertson B 1981 Lung-thorax compliance in the artificially ventilated premature rabbit neonate in relation to variations in inspiration:expiration ratio. Pediatr Res 15:833-838

16. Ikegami M, Jobe AH, Pettenazzo A, Seidner SR, Berry DD, Ruffini L 1987 Effects of maternal treatment with corticosteroids, T3, TRH, and thei combinations on lung function of ventilated preterm rabbits with and without surfactant treatments. Am Rev Respir Dis 136:892-898

17. Enhörning G, Robertson B 1972 Lung expansion in the premature rabbit fetus after tracheal deposition of surfactant. Pediatrics 50:58-66

18. Fujita Y, Kogishi K, Suzuki Y 1988 Pulmonary damage induced in mice by monoclonal antibody to proteins associated with pig pulmonary surfactant Exp Lung Res 14:247-260

19. Suzuki Y, Robertson B Fujita Y Grossmann G 1988 Respiratory failure in mice caused by a hybridoma making antibodies to the $15 \mathrm{kDa}$ surfactant apoprotein. Acta Anaesthesiol Scand 32:283-289

20. Stevens PA, Wright JR, Clements JA 1987 Changes in quantity, composition, and surface activity of alveolar surfactant at birth. J Appl Physiol 63:10491057

21. Robertson B 1987 Pathology of neonatal surfactant deficiency. Perspect Pediatr Pathol 11:6-46

22. Nilsson R, Grossmann G, Robertson B 1978 Lung surfactant and the pathogenesis of neonatal bronchiolar lesions induced by artificial ventilation. Pediatr Res 12:249-255

23. Simon RH, Ward PA 1988 Adult respiratory distress syndrome. In: Gallin JI, Goldstein IM, Snyderman R (eds) Inflammation: Basic Principles and Clinical Correlates. Raven Press, New York, pp 815-827

24. Strayer DS, Merritt TA, Lwebuga-Mukasa J, Hallman M 1986 Surfactant-antisurfactant immune complexes in infants with respiratory distress syndrome. Am J Pathol 122:353-362 